Boom juridisch
Postbus 85576
2508 CG Den Haag
T (070) 3307033
E info@bju.nl
I www.boomjuridisch.nl

Afl. 2018-01
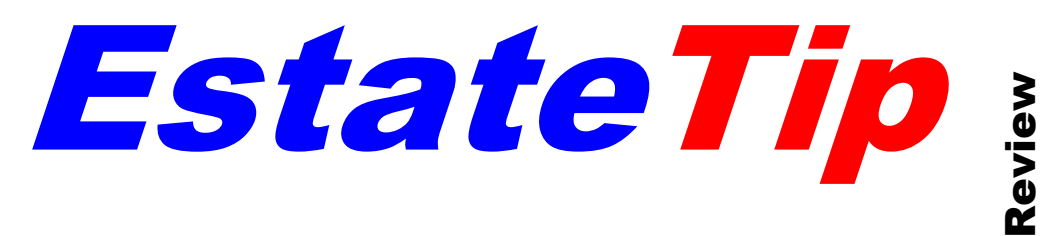

\title{
Pensioen en bijstand, (g)een gelukkige combinatie? (III)
}

De Pensioenwet (PW) biedt de deelnemer vele keuzemogelijkheden. Zo kennen we het uitruilen van ouderdomspensioen in partnerpensioen en vice versa, artikel 60 en $61 \mathrm{PW}$, constructies die de hoogte van de pensioenuitkering gedurende specifieke periodes laat verschillen, artikel $63 \mathrm{PW}$ en uiteraard de optie om het pensioen eerder dan wel later in te laten gaan, artikel 62 lid 1 aanhef en onder b PW. De gevolgen van het vervroegen van de ingangsdatum van diens pensioen door een bijstandsgerechtigde is al eerder aan de orde gekomen in EstateTip Review, zie 2015-22 en 2015-26.

Het is algemeen bekend dat door de (continue) verhoging van de AOW-leeftijd er een groep werknemers is die in de problemen komt. Die problemen worden veelal veroorzaakt door het fysiek zware werk dat niet tot de pensioenleeftijd leeftijd kan worden volgehouden of doordat men om een andere reden geen baan meer heeft. Als in die situatie een beroep gedaan wordt op de bijstand, kan de oudere bijstandsgerechtigde in de verleiding komen om de bijstandsuitkering aan te vullen. Een mogelijke 'aanvulroute' is de suppletie van het bijstandsinkomen met een stukje ouderdomspensioen door dit eerder dan de (beoogde) pensioendatum in te laten gaan. Vervroeging betekent vanzelfsprekend dat het voor de oorspronkelijke pensioendatum berekende ouderdomspensioen dan wel lager uitvalt.

Hoe verhoudt deze 'slimmigheid' zich tot het recht op bijstand? Recht op bijstand bestaat zodra er geen middelen zijn om in de noodzakelijke kosten van het bestaan te voorzien, artikel 11 Participatiewet (Pw). Tot de middelen worden gerekend alle vermogens- en inkomstenbestanddelen waarover men beschikt of redelijkerwijs kan beschikken, artikel 31 lid $1 \mathrm{Pw}$. Het inkomensbegrip treffen we aan in artikel $32 \mathrm{Pw}$. Uit het eerste lid volgt dat niet alleen inkomen uit arbeid, vermogen en socialezekerheidsuitkeringen onder het inkomen vallen maar ook hetgeen 'naar hun aard met deze inkomsten overeenkomt'. In EstateTip Review 2015-22 is gemeld dat de wetgever het onwenselijk vindt als gemeenten bijstandsgerechtigden zouden kunnen dwingen tot het naar voren halen van de ingangsdatum van het tweede pijlerpensioen. Een daartoe strekkende bepaling is opgenomen in artikel 15 lid 2 aanhef en onder a Pw.

Een bijstandsgerechtigde kan dus niet door de gemeente worden gedwongen tot het vervoegen van diens pensioendatum. Maar wat als de bijstandsgerechtigde daartoe zelf (vrijwillig) overgaat? Of wat als - los van het vervroegingsvraagstuk - het ouderdomspensioen tot uitkering komt voordat de AOW-leeftijd is bereikt?

Worden de (vrijwillig vervroegde) termijnen van het ouderdomspensioen voor de bijstand tot het inkomen en/of vermogen gerekend? Als dit het geval is, wordt de bijstand verlaagd met de pensioentermijnen. 
Een uitspraak van de Centrale Raad van Beroep (25 april 2017, ECLI:NL:CRVB:2017:2088) geeft het antwoord. Kort enkele feiten. De bijstandsgerechtigde in deze zaak had op 13 december 2014 de 65-jarige leeftijd bereikt, de AOW-leeftijd werd op 13 maart 2015 bereikt en het ABP keerde vanaf december 2014 ouderdomspensioen uit. De bijstandsverstrekkende gemeente beschouwt het ABP-pensioen als inkomen in de zin van artikel $32 \mathrm{Pw}$ en kort op de uitkering.

Uit de overwegingen van de Centrale Raad halen we het betoog van de bijstandsgerechtigde waarin hij verwoordt waarom het standpunt van de gemeente niet klopt:

'3. [...] Voorts heeft zij aangevoerd dat het ABP-pensioen moet worden aangemerkt als vermogen dat in termijnen wordt uitgekeerd en waarmee de vermogensgrens niet wordt overschreden en niet als inkomen in de zin van de WWB. Voor het geval het ABP-pensioen wel als inkomen moet worden aangemerkt, heeft zij aangevoerd dat het tot aan de wetswijziging van de AOW, waarmee het recht op AOW tot na het bereiken van de leeftijd van 65 jaar is verschoven, de bedoeling van het opbouwen van een aanvullend pensioen is geweest dat de gerechtigden dit in aanvulling op de AOW zouden genieten. Het college gaat dan ook met het in mindering brengen van het AOW-pensioen op de bijstand voorbij aan de bedoeling van de pensioenvoorziening.[...] In elk geval had het college op grond van artikel 33, vijfde lid, van de PW een vrijlating moeten toepassen. Tot slot heeft appellante aangevoerd dat het in mindering brengen van het pensioen op de bijstand kennelijk onredelijk is.' (Curs. FH)

Kort samengevat is het eerste argument dat het ABP-pensioen vermogen is. Vervolgens stelt men dat, aangezien het vermogen van de bijstandsgerechtigde onder de vrijlatingsgrens blijft, het niet in aanmerking mag worden genomen. Het derde argument is dat door de pensioenuitkering in mindering te brengen op de bijstandsuitkering in strijd wordt gehandeld met doel en strekking van pensioenen in de tweede pensioenpijler. Tot slot betoogt men dat de vrijstelling van artikel 33 lid $5 \mathrm{Pw}$ ten onrechte niet is toegepast en dat de korting onredelijk is.

Het woord is aan de Centrale Raad van Beroep:

'4.3. De aan appellante over de maand december 2014 betaalde (maandelijkse) pensioengelden zijn middelen die periodiek worden ontvangen en betrekking hebben op een periode waarover appellante een beroep op bijstand heeft gedaan. Die pensioengelden zijn daarom te beschouwen als inkomen in de zin van artikel 32, eerste lid, van de WWB en niet als vermogen [...]' (Curs. FH)

De pensioentermijnen tellen voor de bijstand 'gewoon' als inkomen. Dus moet de Raad oordelen over de strekking van het aanvullende tweede pijlerpensioen en het toepassen van de vrijstelling:

'4.4. Ook de beroepsgrond dat het college op grond van artikel 33, vijfde lid, van de WWB een vrijlating had moeten toepassen, treft geen doel. Voor het in aanmerking komen voor de bedoelde vrijlating is vereist dat de betrokkene de pensioengerechtigde leeftijd heeft bereikt. De pensioengerechtigde leeftijd is op grond van artikel 1 , onder $\mathrm{m}$, van de WWB de pensioengerechtigde leeftijd als bedoeld in de AOW. Deze leeftijd heeft appellante eerst in maart 2015 bereikt. De Raad ziet voorts, gelet op het complementaire karakter van de WWB, geen ruimte om aan een uitzonderingsbepaling als artikel 33 van de WWB een strekking toe te kennen die ruimer is dan die waartoe de tekst van de bepaling aanleiding geeft. Daarvoor is in dit geval te minder aanleiding omdat blijkens de wetsgeschiedenis 
met de vrijlating is bedoeld een gelijke behandeling mogelijk te maken tussen degenen met alleen een als periodieke uitkering ontvangen oudedagsvoorziening en degenen waarvan de aanvulling op de AOW-uitkering bestaat uit de vrijgelaten rente (artikel 31, tweede lid, onderdeel i) over het bescheiden vermogen (Kamerstukken II 2002-2003, 28 870, nr. 3, p. 60-61).' (Curs. FH)

En tot slot:

'4.5. Tot slot biedt de WWB, anders dan bijvoorbeeld het Inkomensbesluit AOW 1996, dat in de meergenoemde tussenuitspraak aan de orde was, geen ruimte voor een redelijkheidstoetsing van het in mindering brengen van het ABPpensioen op de bijstand, zoals appellante voorstaat. Dat appellante als gevolg van de verhoging van de AOW-gerechtigde leeftijd gedurende enkele maanden tegelijkertijd bijstand en een ABP-pensioen ontving, maakt niet dat het college de pensioeninkomsten niet op de bijstand in mindering moest brengen. Appellante behield immers in deze periode een inkomen op bijstandsniveau, wat in overeenstemming is met het complementaire karakter van de bijstand, die geen basisinkomen vormt, maar voorziet in aanvulling van de eigen middelen van een betrokkene tot een minimuminkomen.' (Curs. FH)

Als we door alle techniek van de Participatiewet heen kijken, lijkt de boodschap helder. De Centrale Raad van Beroep is het met de gemeente eens. Althans, in zoverre dat als om wat voor reden het pensioen in de tweede pijler, in casu het ABP-pensioen, tot uitkering komt tijdens de bijstandsperiode, de uitgekeerde pensioentermijn inkomen is als bedoeld in de Participatiewet. En dus wordt de bijstandsuitkering verlaagd.

Een door de bijstandsgemeente 'afgedwongen' vervroeging van het pensioen is niet (meer) aan de orde. Desalniettemin lijkt een vrijwillige vervroeging of het anderszins voor het bereiken van de AOW-leeftijd samenvallen van bijstand en uitkering van een tweede pijlerpensioen niet zonder gevolgen te blijven. Interessant in dat kader is de vraag of het vrijwillig uitstellen door de bijstandsgerechtigde van het pensioen tot de AOW-leeftijd soelaas biedt. Niet uit te sluiten is dat dit vrijwillig uitstel aangemerkt kan worden als een 'tekortschietend besef van verantwoordelijkheid voor de voorziening in het bestaan', artikel $18 \mathrm{Pw}$, en dat dus sancties dreigen.

Tja, wat men van deze uitspraak ook moge vinden, duidelijk is in ieder geval dat de estate planner die zich beweegt op het scheidsvlak van pensioen en bijstand alert moet zijn.

Tot volgende week.

Mr. F.M.H. Hoens

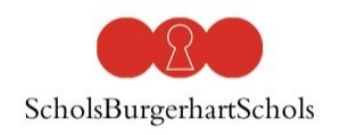

\section{Boomjuridisch}

www.scholsburgerhartschols.nl www.boomjuridisch.nl 